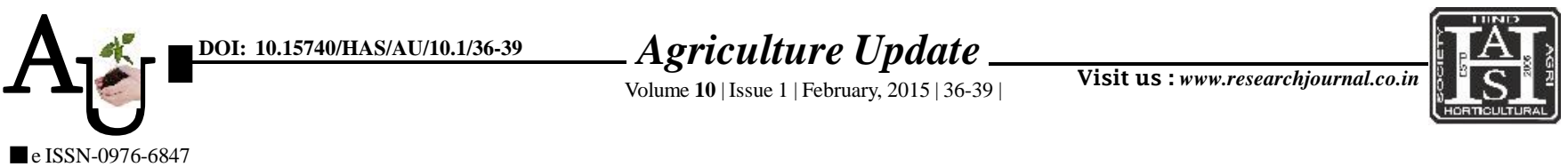

\title{
Research article: Constraints faced by bhil (tribal) farmers in availing benefits of development programmes and their solutions
}

\author{
PRAKASH L. PATEL*, SUMIT R. SALUNKHE AND MUKESH A. KOLI
}

Article Chronicle :

Received :

25.11.2014;

Revised :

30.12.2014;

Accepted :

15.01.2015
SUMMARY : The present study was carried out in Nandurbar district of Maharashtra state to analyze constraints faced by bhil farmers in availing benefits of the schemes of development programmers and solutions to overcome those constraints. Total 20 villages from four selected talukas were identified for the present study. Ex post facto research design was used and 200 sample sizes were selected for the study by using random sampling method. The data were collected by personal interview method. The collected data were analyzed by using appropriate method of analysis viz., percentage, mean, rank, standard deviation and correlation co-efficient. Overwhelming majority $(85.50 \%)$ of the bhil farmers stated that the lack of awareness about various developmental programmers or schemes and $(75.00 \%)$ delays in implementation of schemes is an obstacle in availing the benefits. The delay in sanction (66.50\%), inadequacy of guidance thorough concern officer (64.50\%), for some schemes and majority of the bhil farmers had suggested that to make available the information about various developmental programmers $(80.00 \%)$.

How to cite this article : Patel, Prakash L., Salunkhe, Sumit R. and Koli, Mukesh A. (2015). Constraints faced by bhil (tribal) farmers in availing benefits of development programmes and their solutions. Agric. Update, 10(1): 36-39.

\section{Key Words :}

Constraints,

Developmental

programmers
Author for correspondence :

PRAKASH L. PATEL

Department of Extension Education, K.V. Patel

College of Agriculture, Shahada, NANDURBAR (M.S.) INDIA

Email:saac555@gmail.

com

See end of the article for

authors' affiliations 